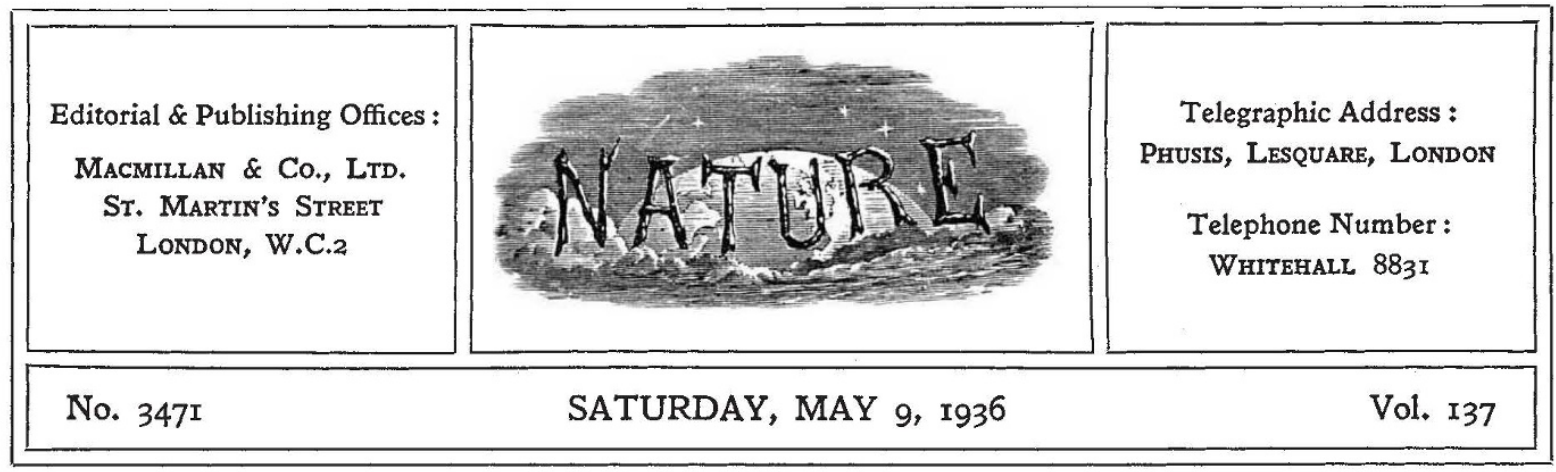

\title{
War, Science and Citizenship
}

$\mathrm{F}$ IELD-MARSHAL LORD ALLENBY, in his rectorial address delivered at the University of Edinburgh on April 28, when he was installed as Lord Rector of the University, gave the students a noble message for the future of humanity. $\mathrm{He}$ condemned war between nations in unmeasured terms as futile in itself and perilous to the highest needs of civilisation. "Wars," he said, "have been usually waged for the spoils of victory, increase of territory, acquisition of wealth, even glory to the victor. The lust for expansion is not yet dead, but the glory of conquest is departing, its gains are Dead Sea fruit, its legacy bitter memories alone. We find the cleverest brains everywhere busily experimenting with new inventions for facilitating slaughter, building more horrible engines of destruction, brewing more atrocious poisons, designing more monstrous methods of murdering their fellow-men and women.... Governments, distrusting treaty makers, no longer hold treaties in respect, regarding them as merely temporary makeshifts."

The use of poison gas in Abyssinia, and the unprovoked attack upon the country, are examples of a breach of covenant and disregard of international obligations which have been condemned by all civilised peoples. These outrages on humanity have raised again the question of the association of science with war and the prostitution of scientific effort to war purposes. No scientific worker will underestimate the difficulties which confront the Italian chemists who reprobate the abuse of scientific knowledge and work in this manner in a State where freedom of scientific thought and effort have long been proscribed. The danger and the problem are, however, far from being confined to Italy. We need look no further than the preparations for national defence stimulated by the British Government in pursuance of the policies outlined in the White Paper on Defence, and the activities in respect of aerial defence which are outlined in the handbooks on Air Raid Precautions being published by H.M. Stationery Office.

Individual manufacturers and local councils are participating in these preparations, if only through the fear of incurring the anger of those who did survive if no precautions had been, attempted. Besides this, however, professional and other associations of scientific workers are being led to participate in various ways; and the responsibility which lies on such associations is far greater than that which rests on the non-technical or non-scientific municipal or district council or manufacturer. Despite the action of individual scientific workers, it is disheartening to find that no association of scientific men has yet had the courage to express a frank opinion on the exact value of this effort and the security it can confer.

There is no more disturbing sign in the present situation than the absence of such an authoritative pronouncement, with the social outlook and acceptance of civic responsibility which it implies. While most scientific workers would not wish to avoid participating in the task of national defence, and in so doing to see that the highest possible efficiency is secured, they would be disloyal to their trust if they do nothing to prevent the creation of a sense of false security, or to make known the extent to which authoritative and expert opinion regards defence against aerial bombardment, whether by incendiary, high explosive or gas bombs, separately or simultaneously, as practicable. 
To neglect all precautions would be foolish, but scarcely more foolish than allowing the population to believe that effective defence is possible, or to remain ignorant of the acute dangers which would attend the severing of, for example, the Great London sewer at Barking or the new Mersey tunnel, and the extreme vulnerability of such points to high explosive or gas bombs. Moreover, since complete defence is impossible, authorities have recognised that victory in the next war will go to the country whose population and industrial organisation show the greatest degree of staying power and endurance. Accordingly, populations are being trained and organised to develop staying power and endurance, and the scattering of individuals and industries to enhance staying power has already begun in some of the threatened countries, with consequences to social amenities and the preservation of natural beauty which may be irreparable, as they are for the present disregarded.

The misdirection of scientific effort and national resources in this way is in itself a threat to the continuance of civilisation almost as serious as the outlook of the very warfare against which the precautions are being developed. It is not merely the appropriation in this way, for defence purposes which are largely futile, of large sums of money which might otherwise enable the mass of the population to enjoy that measure of plenty with which science could well endow them. At a recent meeting held in London, Sir John Orr and a group of engineers and other scientific workers assessed the unfulfilled needs of the people of Great Britain with regard to prime human necessities such as food, housing, clothing, health and recreation, at about $£ 3,000,000,000$ a year, including a sum for essential foods of $£ 200,000,000$, which is roughly the cost in goods and services of the activities now being organised with immense care and skill to meet the artificially created danger of aerial bombardment.

Much more serious is the steady deterioration of life which always occurs under a military regime, and to which Lewis Mumford directed atterstion in a brilliant chapter in his "Technics and Civilisation". Under such a regime, the reorientation of civilisation so that the creative forces of society are fully utilised, and mechanisation is the agent and not the master of mankind, becomes more than ever impossible of attainment. Nor can we hope either that technical developments will be made to conform to the elementary spiritual needs of mankind or for the successful elimination of the causes of cultural decay which to-day present an evergrowing menace to the spiritual and rsthetic elements still left to our civilisation.

Whether anything worth preserving can long remain in our civilisation under its present conditions and leadership may well be open to doubt. In a speech at Worcester on April 18, the Prime Minister spoke of the probability of the outraged peoples turning against Governments which allowed the use of poison gas in a European war, after hostilities had ceased. That rising against wickedness in high places may well be much nearer. The ordinary citizen has much to lose by mere acquiescence to the drift of present conditions, in which a dangerous premium is put on revolution and violence. Only constructive statesmanship can avert either revolution or disaster, and in that statesmanship men of science must play their part.

Even the dullest cannot fail to see what is involved in the cynical disregard of international conventions shown by Italy's use of poison gas against a nation utterly unprovided with any means either of defence or reprisal in kind. This shattering of faith in international pledges is accentuated by the evident reluctance of powerful members of the League of Nations to resort to effective means of restraining the aggressor, and the consequences of such default may be far-reaching. The alternative to collective security resolutely enforced is so terrible that it would be rash to predict that any intelligent people will indefinitely allow their rulers to repudiate or disregard their international obligations and plunge all alike in a catastrophe from which there may be no recovery.

Scientific workers should pause to consider whether even yet there is not some decisive contribution which collectively they might make to remedy this condition of our so-called civilisation. It is deplorable that so much effort continues to be expended on destructive purposes while the great constructive enterprises, which might enable mankind to enjoy more fully the great resources with which science has endowed us, remain crippled or uncommenced for lack of funds.

The choice before us could scarcely be better expressed than has been done by Mr. H. A. L. Fisher in his recent "History of Europe" : "The developing miracle of science is at our disposal to use or to abuse, to make or to mar. With science we may 
lay civilisation in ruins or enter into a period of plenty and well-being, the like of which has never been experienced by mankind".

To acquiesce tamely in the present situation is a policy of despair and will assuredly involve scientific workers in the destruction to which civilisation is steadily drifting. To ally themselves boldly with constructive political forces, to apply the spirit and method of science to the elaboration in the political and social spheres of ways and means of control, of relating power to knowledge, may yet avert disaster and enable the world to reap the advantages which are still within its reach. To do so, however, demands courage, and vision, resource and pertinacity the equal of any which has yet been shown in pioneering investigations in those fields of knowledge within which science has hitherto been largely content to limit its activities.

\section{Modern Methods in the Antarctic}

Antarctic Discovery :

the Story of the Second Byrd Antarctic Expedition. By Rear Admiral Richard Evelyn Byrd. Pp. sxii $+421+47$ plates. (London: Putnam and Co., Ltd., 1936.) 18s, net.

THANKS to the restraint on publicity imposed by the practice of exclusive copyright in news, most English newspaper readers have been kept nearly as ignorant of Admiral Byrd's second expedition to Little America as of the financing of Irish hospitals or evidence in the divorce courts. As a result there has been a vague impression that the expedition was a lavishly equipped pleasure trip intent on photographing films of sensational stunts and making exaggerated claims to amazing discoveries. It is for this reason that I welcome the opportunity of reviewing Admiral Byrd's book and endeavouring as far as I can stretch the allotted space to direct attention to the solid schievements of the expedition.

It must be acknowledged that the book presents some initial difficulties to the reader accustomed only to English books of travel, but these are soon overcome. The chapter headings give little idea of the subjects dealt with ; but a good index goes far to remedy the deficiency. The book is a straightforward narrative vividly and tersely written. The meaning of certain American neologisms can be divined from the context, and even such a cryptic phrase as "commuting to work back home" glimmers into comprehensions as a simile for the monotonous repetition of daily drudgery.

We learn that, like most of our own explorers, Byrd had a hard and distasteful struggle to raise funds and collect stores. $\mathrm{He}$ had to be content with two indifferent ships, an old wooden whaler, the Bear of Oakland, and a common steel tramp, the Jacob Ruppert. On the way out, the latter vessel escorted by a scouting seaplane reached higher latitudes in the South Pacific than had been attained before. This enables the cartographer to push nearly the whole Pacific coast-line of Antarctica south of $73^{\circ} \mathrm{S}$. We notice that the name Marie Byrd Land, given in Admiral Byrd's earlier book "Little America" to a modest area south of King Edward VII Land, is now stretched across the whole great lobe between the Pacific Ocean and the Ross and Weddell Seas.

At the Bay of Whales 400 tons of stores were landed and transported several miles to Little America. The old buildings were found intact, deeply buried in snow on which the new buildings were erected, soon to be drifted over in their turn. The two levels were connected by steep tunnels and a population of 55 men, twice as many dogs and several cows was settled for the winter entirely underground. The extent of this catacomb 'city' was so great that Dog-town alone consisted of eight parallel tunnels, each 100 feet long, 6 feet high and 3 feet wide, with each dog tethered to a crate let into the walls on either side out of reach of its neighbours. The whole was burrowed in a cake of ice probably about 300 feet thick and floating on 600 fathoms of water. In fact, it was a potential iceberg, and a system of crevasses made its permanence very questionable until winter moored it fast.

An advanced base 120 miles to the south (in $80^{\circ} \mathrm{S}$.) was occupied for the winter by the leader alone, a somewhat surprising arrangement. It was Admiral Byrd's expedition; he was entitled to conduct it as he thought best, and as it was a success the event justified the plan.

"The truth of the matter is," Byrd writes, "I really wanted to go and keenly looked forward to the experience. ... I sincerely believed I was as interested in the experience for its own sake as I was in the meteorological work for which the Base was designed. Therefore I cannot say that I was making a sacrifice for science. That did not 